\title{
Hvitrosa kar i øyebunnen
}
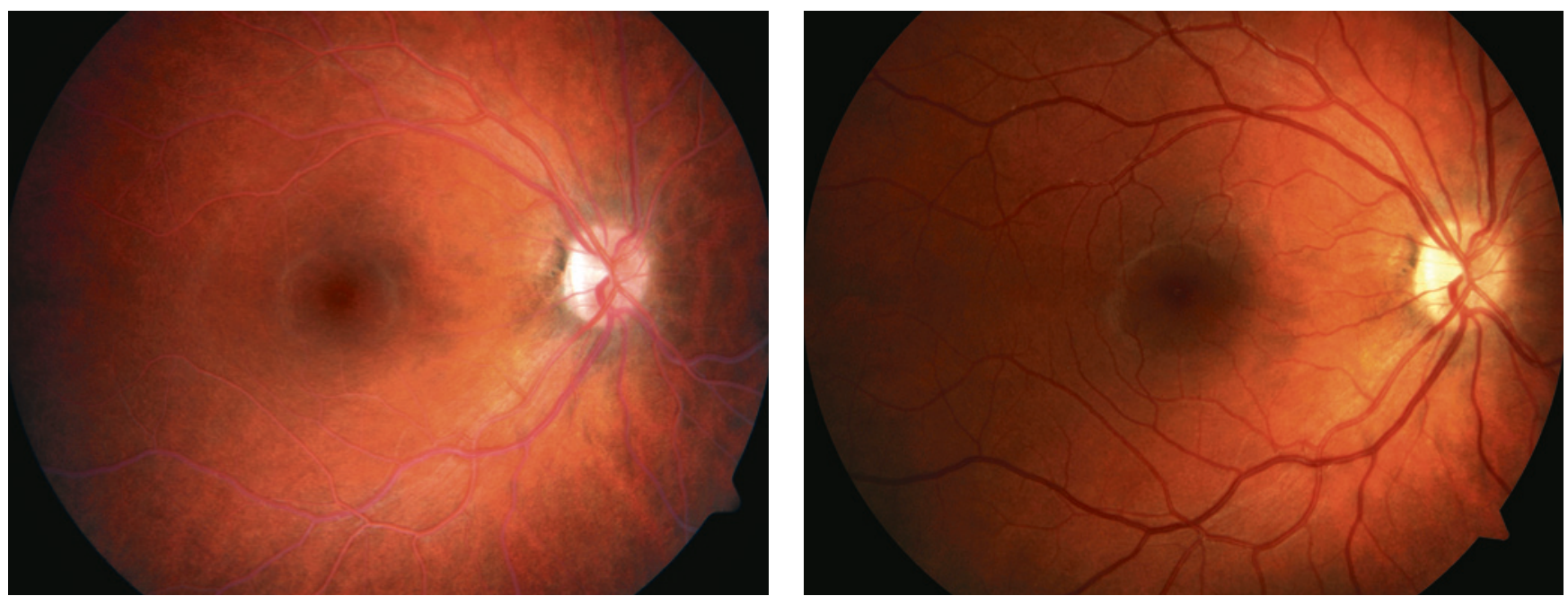

En mann i begynnelsen av 20-årene tok kontakt med legevakt grunnet aksillære sår som ikke ville gro. Han hadde i barnealder blitt behandlet for epilepsi, men var ellers frisk. Blodsukker målt ved legevakten viste en verdi på $21,2 \mathrm{mmol} / \mathrm{log}$ han ble derfor akuttinnlagt i medisinsk avdeling under diagnosen nyoppdaget diabetes. Blodprøver under innleggelsen viste ingen acidose, totalkolesterol $14,5 \mathrm{mmol} / \mathrm{l}(2,9-6,1 \mathrm{mmol} / \mathrm{l})$, triglyserider 71,4 mmol/1 $(0,45-2,60 \mathrm{mmol} / \mathrm{l})$, $\mathrm{HbA}_{1 \mathrm{c}} \quad 11,6 \% \quad(4,0-6,0 \%)$ og C-peptid $2204 \mathrm{pmol} / \mathrm{l}$ (220-1 $400 \mathrm{pmol} / \mathrm{l})$. Diagnosen nyoppdaget diabetes mellitus type 2 ble stilt. Anti-GAD og anti-IA2, som kan være forhøyet ved autoimmun diabetes, kunne ikke utføres grunnet sterkt lipemisk serum.

Pasienten hadde ingen synsplager, men ble henvist til øyelege for rutinemessig undersøkelse med tanke på diabetisk retinopati. Øyelegevurderingen viste normal visus og pene forhold i øyets fremre segment. Ved oftalmoskopi ble det sett påfallende kremfargede hvitrosa funduskar (bildet til venstre). Dette funnet har betegnelsen lipemia retinalis og er en sjelden tilstand som kan ses ved meget høye verdier av triglyserider (1). Pasienten hadde ingen familiær historie med hyperlipidemi. Hyperlipidemien ble derfor i første omgang tolket som sekundær til hyperglykemi/diabetes. Det ble startet behandling med insulin, metforminhydroklorid under opptrapping og atorvastatin $40 \mathrm{mg} \times 1$.
Lipemia retinalis kan skyldes både primær og sekundær hyperlipidemi. Hyperlipidemi uten triglyseridemi vil ikke gi dette bildet. I tillegg til de karakteristiske karforandringene kan hele fundus også være lakserosa i fargen. Spredning av lys når lyset treffer kylomikroner er tenkt å være forklaringen på den karakteristiske fargen. De tidligste tegnene på denne tilstanden finnes i perifere retina. Når nivået av triglyserider øker, ser man også forandringer i øyets bakre pol. Tilstanden er reversibel og går raskt tilbake når hyperlipidemien normaliseres. Man har ment at plasma-triglyseridnivået må være $2500 \mathrm{mg} /$ dl, som tilsvarer omtrent $30 \mathrm{mmol} / 1$ for å finne lipemia retinalis (1). Det er ingen forandring i netthinnens perfusjon og pasientene har normalt visus. Ved elektroretinografi er det beskrevet reduserte a- og b-bølger i stavog tappresponser.

Kontroll nesten åtte måneder etter utskrivning viste normalisering av netthinnefoto (bildet til høyre). Totalkolesterol var da $3,9 \mathrm{mmol} /$ 1, HDL-kolesterol 0,7 mmol/1, LDL-kolesterol 2,5 mmol/1, triglyserider $2,1 \mathrm{mmol} / \mathrm{l}$ og $\mathrm{HbA}_{1 \mathrm{c}}$ $6,9 \%$. Medisinering ved dette tidspunktet er kun metforminhydroklorid $500 \mathrm{mg} \times 2$.

Lipemia retinalis er et viktig oftalmologisk tegn på en potensielt alvorlig metabolsk sykdom, noe spesielt øyeleger bør kjenne til.

Pasienten har gitt samtykke til at artikkelen blir publisert.
Takk til Øyeavdelingen, Universitetssykehuset NordNorge for oppfølgende fundusfoto.

\section{Kristoffer Ommundsen}

kristoffer.ommundsen@helse-mr.no

Augeavdelinga

Kirurgisk klinikk

\section{Hilde Selsås}

Endokrinologisk seksjon

Medisinsk avdeling

Ålesund sjukehus

Kristoffer Ommundsen (f. 1985) er lege i spesialisering

Forfatter har fylt ut ICMJE-skjemaet og oppgir ingen interessekonflikter.

Hilde Selsås (f. 1972) er seksjonsoverlege. Forfatter har fylt ut ICMJE-skjemaet og oppgir ingen interessekonflikter.

\section{Litteratur}

1. Zahavi A, Snir M, Kella YR. Lipemia retinalis: case report and review of the literature. J AAPOS 2013; 17: $110-1$.

Mottatt 10.4. 2015, første revisjon innsendt 14.5. 2015, godkjent 27.5. 2015. Redaktør: Lars Frich.

Engelsk oversettelse på www.tidsskriftet.no 